ИЗВЕСТИЯ АКАДЕМИИ НАУК ЭСТОНСКОП ССР. ТОМ 29

ГЕОЛОГИЯ. 1980, № 4

\title{
ГИДРОГЕОЛОГИЧЕСКИЕ УСЛОВИЯ СЕВЕРО-ВОСТОЧНОИ ЧАСТИ ЗОНЫ АХТМЕСКОГО ТЕКТОНИЧЕСКОГО НАРУШЕНИЯ
}

Ахтмеское нарушение изучалось с перерывами в течение длительного периода. В последние годы проведены комплексные опытные работы в северо-восточной части нарушения. На границе полей шахт «Ахтме»

и «Виру» была сделана попытка пересечь нарушение горноразведочной выработкой (V северным панельным штреком шахты «Ахтме») c целью достоверного изучения его строения и оценки горногеологических и гидрогеологических условий на горизонте промышленного пласта горючих сланцев. В створе выработки предварительно был пробурен профиль картировочных скважин через $30-50$ м и 4 гидронаблюдательные скважины на кейла-кукрузеский (№ 7300г/г, 8332г) и ласнамяэ-кундаский (№ 7301г/г, 8333г) водоносные горизонты.

Проходка штрека осуществлялась с сентября 1975 г. по январь 1978 г. с перерывами, поэтому при анализе гидрогеологических наблюдений приходилось учитывать сезонный и временной факторы. Проходился штрек по промышленному пласту сланца или породам непосредственной кровли. Общая ширина нарушения, определенная по осложнению гипсометрии промышленного пласта на исследуемом участке, составляет 500 м, ширина нарушения, вскрытая штреком, $220 \mathrm{M}$.

Согласно гидростратиграфической схеме, применяемой в настоящее время при разведке горючих сланцев на Эстонском месторождении, обводняющий горные выработки ордовикский водоносный комплекс представлен (сверху вниз) набала-раквереским, кейла-кукрузеским и ласнамяэ-кундаским водоносными горизонтами.

Основным источником обводнения горных выработок на исследованном учُастке является кейла-кукрузеский водоносный горизонт. В меньшей степени участвуют в обводнении набала-раквереский и ласнамяэ-кундаский водоносные горизонты и воды четвертичных отложений. Влияние поверхностных и атмосферных вод носит сезонный характер. Основные характеристики водоносных горизонтов приведены в табл. 1, для составления которой использованы результаты опытных откачек из двух гидрогеологических кустов. Один из них расположен на картировочном профиле вблизи оси штрека, другой - в 1,7 км югозападнее (д. Пагари), также в зоне Ахтмеского тектонического нарушения. Всего были опробованы 3 скважины на кейла-кукрузеский и 3 скважины на ласнамяэ-кундаский водоносные горизонты. Характеристика набала-раквереского водоносного горизонта дана по 4 скважинам, расположенным на всей площади развития горизонта в пределах поля шахты «Ахтме». 
Таблица 1

Характеристика водоносных горизонтов

\begin{tabular}{|c|c|c|c|c|c|c|c|c|}
\hline \multirow[b]{2}{*}{$\begin{array}{l}\text { Водонос- } \\
\text { ный } \\
\text { горизонт }\end{array}$} & \multirow[b]{2}{*}{$\begin{array}{c}\text { Характер } \\
\text { распро- } \\
\text { стране- } \\
\text { ния }\end{array}$} & \multirow[b]{2}{*}{$\begin{array}{c}\text { Характер } \\
\text { уровня } \\
\text { воды }\end{array}$} & \multirow{2}{*}{ 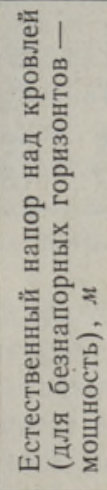 } & \multirow{2}{*}{ 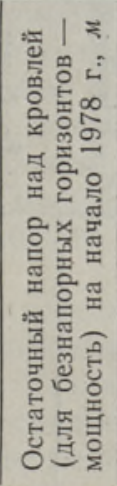 } & \multicolumn{2}{|c|}{$\begin{array}{c}\text { Удельные дебиты } \\
\text { скважин (пределы } \\
\text { колебаний), } \\
\text { л/сек.м }\end{array}$} & \multicolumn{2}{|c|}{$\begin{array}{c}\text { Коэффициенты } \\
\text { фильтрации (пре- } \\
\text { делы колебаний), } \\
\text { м/султ }\end{array}$} \\
\hline & & & & & $\begin{array}{c}\text { при не- } \\
\text { нару- } \\
\text { шенном } \\
\text { залега- } \\
\text { нии } \\
\text { слоев }\end{array}$ & $\begin{array}{l}\text { в подзо- } \\
\text { нах дроб- } \\
\text { ления и } \\
\text { трещино- } \\
\text { ватости }\end{array}$ & $\begin{array}{c}\text { при } \\
\text { нена- } \\
\text { рушен- } \\
\text { ном } \\
\text { зале- } \\
\text { гании } \\
\text { слоев }\end{array}$ & $\begin{array}{c}\text { в подзонах } \\
\text { дробления } \\
\text { и трещино- } \\
\text { ватости }\end{array}$ \\
\hline $\begin{array}{l}\text { Набала- } \\
\text { раквере- } \\
\text { ский }\end{array}$ & $\begin{array}{l}\text { Выкли- } \\
\text { нивается } \\
\text { в районе } \\
\text { штрека }\end{array}$ & $\begin{array}{l}\text { Безна- } \\
\text { порный }\end{array}$ & до 9,6 & около 4 & \multicolumn{2}{|c|}{$\begin{array}{c}0,87-1,5 \\
\text { (в целом для поля } \\
\text { шахты «Ахтме») }\end{array}$} & \multicolumn{2}{|c|}{$\begin{array}{c}1,07-6,72 \\
\text { (в целом для поля } \\
\text { шахты «Ахтме») }\end{array}$} \\
\hline $\begin{array}{l}\text { Кейла- } \\
\text { кукру- } \\
\text { зеский }\end{array}$ & $\begin{array}{l}\text { Повсе- } \\
\text { местный }\end{array}$ & $\begin{array}{l}\text { Преиму- } \\
\text { ществен- } \\
\text { но без- } \\
\text { напорный }\end{array}$ & $\begin{array}{c}\text { около } \\
40\end{array}$ & $8-10$ & 0,022 & $0,50-1,45$ & 0,18 & $2,66-8,5$ \\
\hline $\begin{array}{l}\text { Ласна- } \\
\text { мяэ-кун- } \\
\text { даский }\end{array}$ & $\begin{array}{l}\text { Повсе- } \\
\text { местный }\end{array}$ & $\begin{array}{l}\text { Напор- } \\
\text { ный }\end{array}$ & $\begin{array}{c}\text { около } \\
60\end{array}$ & 13 & 0,036 & $0,18-0,35$ & 0,18 & $1,21-3,23$ \\
\hline
\end{tabular}

Водовмещающие породы кейла-кукрузеского водоносного горизонта в неизмененном виде представлены слаботрещиноватыми, неравномерно глинистыми известняками с прослоями горючих сланцев. В центральной и юго-восточной частях нарушения (вкрест его) это - преимущественно доломиты и доломитизированные известняки, неравномерно трещиноватые и неравномерно кавернозные, местами раздробленные. В связи с этим отмечаются большие колебания водообильных и водопроницаемых свойств пород (табл. 1). Наибольшие коэффициенты фильтрации получены в подзоне трещиноватых и измененных пород тектонического нарушения.

Воды горизонта безнапорные, уровни снижены под влиянием многолетнего шахтного водоотлива, причем развитие депрессии продолжается.

Верхний оанду-кейлаский относительный водоупор локален и представлен в нормальном поле мергелями и сильно глинистыми известняками мощностью 5-6 $м$. Нижний относительный водоупор повсеместен и хорошо выдержан по площади и разрезу, представлен глинистыми плотными известняками ухакуского горизонта средней мощностью $15 \mathrm{M}$. По данным пробных откачек эти породы в ненарушенных условиях практически безводны. В водосборных штреках шахт приток из них незначителен.

Повышенные трещиноватость и раздробленность пород на отдельных участках нарушения создают условия для затрудненной взаимосвязи водоносных горизонтов. Такая взаимосвязь была обнаружена 


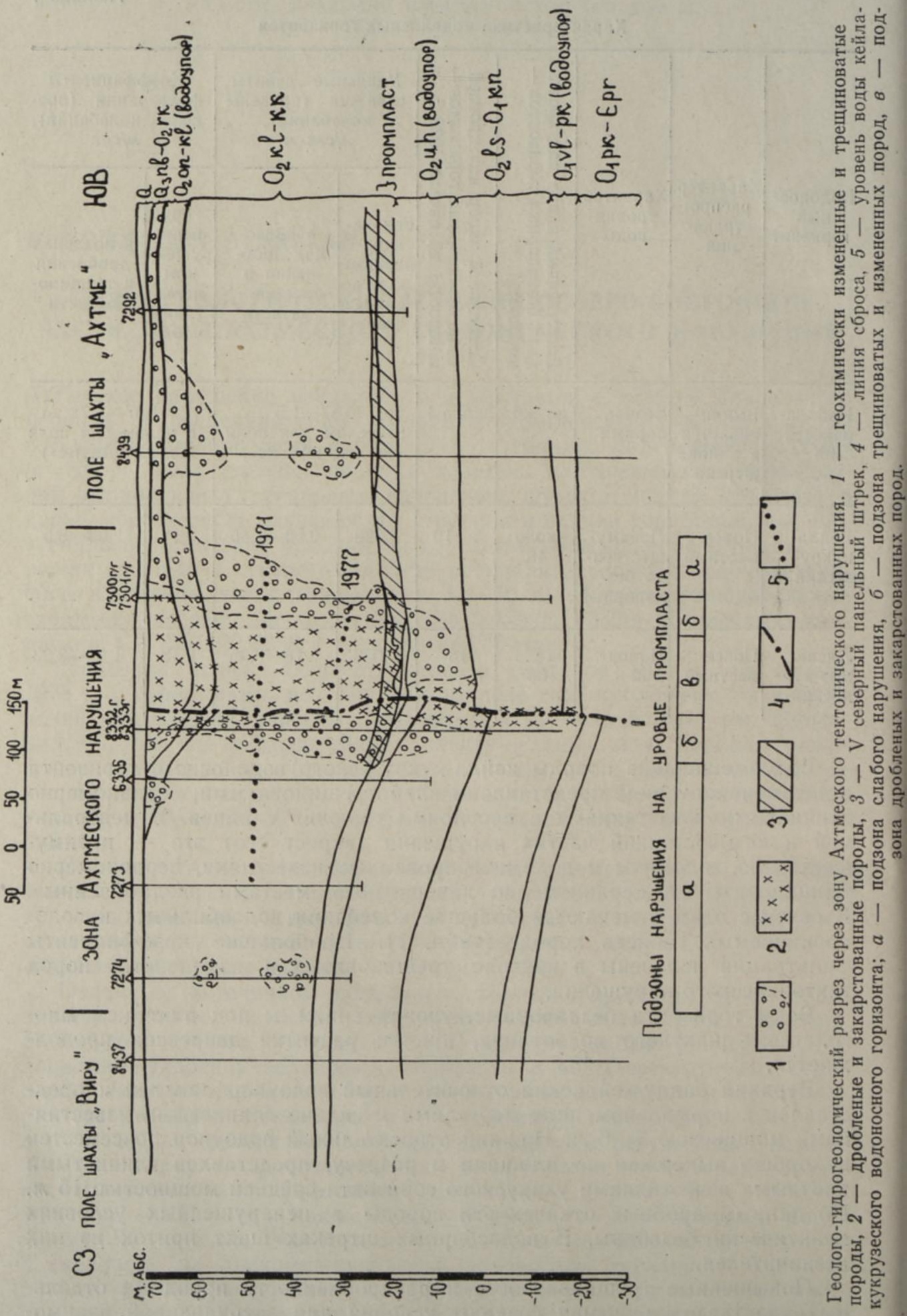


откачками на кусту. гидрогеологических скважин в Пагари, расположенном в 1,7 км юго-западнее опытного участка. Непосредственно в районе штрека (скв. № 7300г/г и 7301г/г, пробуренные в слаботрещиноватых породах) такая связь разведочными работами не установлена.

Состав пород разделяющих слоев на отдельных участках нарушения также изменен - отмечаются доломитизация, мелкие каверны, трещиноватость, но в целом относительно водоупорный характер их сохраняется. Об этом свидетельствует постоянное присутствие воды в верхнем набала-раквереском водоносном горизонте, несмотря на дренирующее влияние горных выработок и некоторых разведочных и технических скважин.

Нижний ласнамяэ-кундаский водоносный горизонт залегает на глубине около 65 м. Водовмещающие породы представлены здесь известняками и доломитами, местами глинистыми, имеющими довольно выдержанную мощность равную в среднем 20 м. Первоначальные напоры снижены на 30-40 м преимущественно за счет технических, эксплуатационных и пылеподавляющих скважин.

Четвертичные отложения представлены в основном безводными гляциальными образованиями мощностью от 2,30 до 6,60 м. Локально (в песчаных разностях) развита верховодка. В общем, роль четвертичных отложений сводится к регулированию питания нижележащего комплекса инфильтрующимися атмосферными осадками, особенно в периоды паводков и осенних дождей. Наличие торфа (до 1 м) и большого количества глинистого материала в толще морены обусловливают затяжной характер процесса просачивания поверхностных вод в горные выработки исследованного участка. В V северном панельном штреке максимальный весенний приток наблюдался почти на месяц позже, чем в целом по шахте.

Характер и степень обводненности штрека определялись структурной зональностью Ахтмеского тектонического, нарушения. По полученным геологическим материалам нарушение в общем трактуется как флексурообразный перегиб пластов, осложненный участками измененных, дробленых и закарстованных пород, вертикальными перемещениями по наиболее ослабленным участкам и формами карстового проседания.

По составу и строению массива горных пород и их нарушенности В. Каттай и П. Вингисааром (1980) проведено структурное зонирование нарушения на уровне промпласта горючих сланцев. Последовательно от периферии к центру нарушения выделяются 3 структурные подзоны (рисунок).

Соответственно структурным подзонам выделены зоны по степени обводненности, имеющие свои качественные и количественные характеристики (табл. 2). Хотя полного совпадения границ структурных подзон и гидрогеологических зон не наблюдается, в целом они хорошо согласуются друг с другом.

Подзона проявления пликативной тектоники или слабого нарушения выделяется в периферийных частях зоны и выражается в более крутом и слабоволнистом залегании пласта от 1 до $4^{\circ}$ (фоновое $10-20$ мин) и в проявлении участками слабой доломитизации пород в перекрывающей толще.

Обводненность подзон пликативной тектоники в обоих крыльях нарушения носила характер слабого капежа.

В подзоне трещиноватых и измененных пород слои имеют наклон от $1-2$ до $18^{\circ}$. Вмещающие породы и известняковые прослои промпласта трещиноваты, доломитизированы, кавернозны; по 
Таблица ?

Основные характеристики структурных подзон и гидрогеологических зон

\begin{tabular}{|c|c|c|c|c|c|}
\hline \multirow[b]{2}{*}{$\begin{array}{c}\text { Структурные } \\
\text { подзоны в пре. } \\
\text { делах нару- } \\
\text { шения }\end{array}$} & \multirow[b]{2}{*}{$\begin{array}{c}\text { Ширина } \\
\text { подзон, } \\
M\end{array}$} & \multicolumn{4}{|c|}{$\begin{array}{c}\text { Гидрогеологические зоны в пределах вскрытой штреком } \\
\text { части нарушения }\end{array}$} \\
\hline & & $\begin{array}{c}\text { Ширина } \\
\text { зон, } \\
M\end{array}$ & $\begin{array}{c}\text { Характерные } \\
\text { структурные и } \\
\text { морфологиче- } \\
\text { ские особен- } \\
\text { ности }\end{array}$ & $\begin{array}{l}\text { Характер поступления } \\
\text { воды }\end{array}$ & $\begin{array}{l}\text { Дебит } \\
\text { зоны, } \\
\text { л/сек }\end{array}$ \\
\hline $\begin{array}{lr}\text { Подзона } & \text { про- } \\
\text { явления } & \text { плика- } \\
\text { тивной } & \text { текто- } \\
\text { ники } & \text { юго-вос- } \\
\text { точного } & \text { крыла }\end{array}$ & 70 & 90 & $\begin{array}{l}\text { Слабое погру- } \\
\text { жение слоев в } \\
\text { северо-запад- } \\
\text { ном направле- } \\
\left.\text { нин (до } 2^{\circ}\right)\end{array}$ & $\begin{array}{l}\text { Трещины в основном су- } \\
\text { хне, местами по ним от- } \\
\text { мечается небольшое выса- } \\
\text { чнвание; незначительная } \\
\text { течь в виде тонких струй } \\
\text { из-под штанговой крепи }\end{array}$ & $\begin{array}{l}\text { Зона } \\
\text { слабого } \\
\text { капежа }\end{array}$ \\
\hline $\begin{array}{lr}\text { Подзона } & \text { тре- } \\
\text { щиноватых } & \text { и } \\
\text { измененных по- } \\
\text { род юго-вос- } \\
\text { точного крыла }\end{array}$ & 35 & 15 & $\begin{array}{l}\text { Интенсивный } \\
\text { подъем слоев } \\
\left(8-12^{\circ}\right) \text {, силь- } \\
\text { ная трещинова- } \\
\text { тость и раз- } \\
\text { дробленность } \\
\text { пород }\end{array}$ & $\begin{array}{llr}\text { Обильные выходы } & \text { воды } \\
\text { из-под штанг и нз } & \text { полу- } \\
\text { сомкнутых трещин } & \text { С-3 } \\
\text { простирания } & & \end{array}$ & Около 4 \\
\hline $\begin{array}{l}\text { Центральная } \\
\text { подзона дроб- } \\
\text { леных и закар- } \\
\text { стованных по- } \\
\text { род }\end{array}$ & 80 & 80 & $\begin{array}{l}\text { Остаточные } \\
\text { карстовые гли- } \\
\text { ны перемежа- } \\
\text { ются участками } \\
\text { дробленых по- } \\
\text { род протяжен- } \\
\text { ностью до } \\
5-6 \text { м }\end{array}$ & $\begin{array}{l}\text { На участках дробления } \\
\text { наблюдались сильные вы- } \\
\text { ходы воды из вертикаль- } \\
\text { ных трещин С-3 и С-В } \\
\text { простирания, из бессистем- } \\
\text { ных трещинок в виде } \\
\text { сплошного капежа, на кон- } \\
\text { тактах доломита и карс- } \\
\text { товой глины }\end{array}$ & \\
\hline $\begin{array}{lr}\text { Подзона тре- } \\
\text { щиноватых } \\
\text { измененных по- } \\
\text { род северо-за- } \\
\text { падного крыла }\end{array}$ & 45 & $10-12$ & 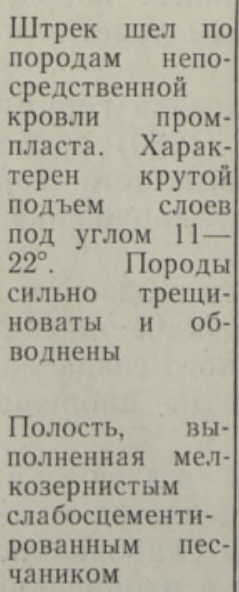 & $\begin{array}{l}\text { Вода поступала из шпу- } \\
\text { ров, горизонтальных по- } \\
\text { лостей, трещин. Дебиты } \\
\text { отдельных шпуров } 0,11- \\
1,04 \text { л/сек. Трещины об- } \\
\text { воднены на всем протя- } \\
\text { женин, дебиты отдельных } \\
\text { струй } 0,6-6 \text { л/сек. Из по- } \\
\text { лости в } 2,5 \text { в выше кров- } \\
\text { ли слоя «Н» наблюдался } \\
\text { сплошной выход воды с } \\
\text { дебитом струй } 0,18-4,3 \\
\text { л/сек } \\
\text { Полость явилась источни- } \\
\text { ком прорыва воды и песка }\end{array}$ & $13-14$ \\
\hline $\begin{array}{lr}\text { Подзона } & \text { про- } \\
\text { явления } & \text { плика- } \\
\text { тивной } & \text { текто- } \\
\text { ники } & \text { северо- } \\
\text { западного } & \text { кры- } \\
\text { ла } & \end{array}$ & 270 & 18 & $\begin{array}{l}\text { Выполаживание } \\
\text { угла подъема } \\
\text { слоев до } 5-3^{\circ}\end{array}$ & Слабый капеж из трещин & $\begin{array}{l}\text { Слабово- } \\
\text { доносная } \\
\text { зона }\end{array}$ \\
\hline
\end{tabular}


слоям горючих сланцев отмечается трещиноватость, выветрелость, разрыхленность, усиливающиеся к центру нарушения. Вскрыта карстовая полость, заполненная. мелкозернистым слабосцементированным песчаником.

Соответствующие этим подзонам гидрогеологические зоны выделены очень четко, причем в северо-западном более крутом крыле эта зона была значительно водообильнее такой же зоны в юго-восточном крыле. В двух случаях поступление воды в северо-западную зону происходило в виде прорыва: при вскрытии горизонтальной полости под кровлей штрека протяженностью 1,5 м и при вскрытии карстовой полости, выполненной водоносным мелкозернистым слабосцементированным песчаником. Полость максимальной длиной 6,2 м явилась источником прорыва воды и песка с дебитом около 60 几/сек. По всей вероятности, вглубь полость не распространяется ниже ухакуского горизонта, так как уровень воды в ближайшей скв. № 8333г на ласнамяэ-кундаский водоносный горизонт на прорыв не реагировал, тогда как в скв. № 8332г на кейла-кукрузеский водоносный горизонт (в 3 м от скв. № 8333г) упал на 1,58 м. Максимальный приток в штрек при прорыве достиг 80 л/сек. Так как вскрытая далее штреком подзона пликативной тектоники была слабоводоносной, водоприток в штрек за 1,5 месяца снизился до $50 \Omega /$ сек.

Подзона дробленых и закарстованных пород занимает условно центральную часть нарушения. В этом интервале по вєем стратиграфическим горизонтам, залегающим выше промпласта, отмечается доломитизация, повышенная трещиноватость, дробленость, каверозность и закарстованность коренных карбонатных пород, волнистость в залегании пластов, вертикальные смещения вдоль ослабленных участков и общее уменьшение мощности горизонтов. Слои промышленного пласта замещены участками карстовой глины и на ней лежат просевшие, сильно измененные породы непосредственной кровли. Аналогичные явления были отмечены в шахтах Ленинградского месторождения горючих сланцев (Левин, 1973). По структурной зональности карстовых нарушений интервал соответствует зоне остаточных глин (Газизов, 1971).

В подзоне дробленых и закарстованных пород остаточные глины перемежались сильнотрещиноватыми раздробленными обводненными доломитами. Там, где штрек шел почти на все сечение по глине, наблюдались очень незначительные выходы воды. Общий дебит подзоны определить не удалось, так как проходка ее осуществлялась с марта 1976 г. по сентябрь 1977 г. и с длительными перерывами. В период весеннего паводка 1976 г. водоприток в штрек увеличился в 1,7 раза (по сравнению с предпаводковым), а в паводок 1977 г. - в 1,3 раза. При перерыве в проходке штрека в меженный период на 8 месяцев (с июня 1976 г. по март 1977 г.) водоприток снизился в 3 раза. Для сравнения необходимо отметить, что коэффициент сезонной неравномерности общешахтного водопритока в эти годы составил соответственно 3,68 и 3,76 при минимальных значениях за последние 10 лет наблюдений $1,79-2,98$ и максимальном - 4,08- в 1971 г.

Общее снижение среднемесячных уровней воды по наблюдательным скважинам за весь период проходки штрека (сентябрь 1975 - январь 1978) составило: в кейла-кукрузеском водоносном горизонте - 11,19 $\mathrm{M}$, в кейла-кукрузеском и набала-раквереском водоносных горизонтах совместно - 2,52 м. В ласнамяэ-кундаском горизонте снижения по среднемесячным значениям не отмечено (табл. 3). 
таблица 3

Среднемесячные уровни воды за период проходки штрека

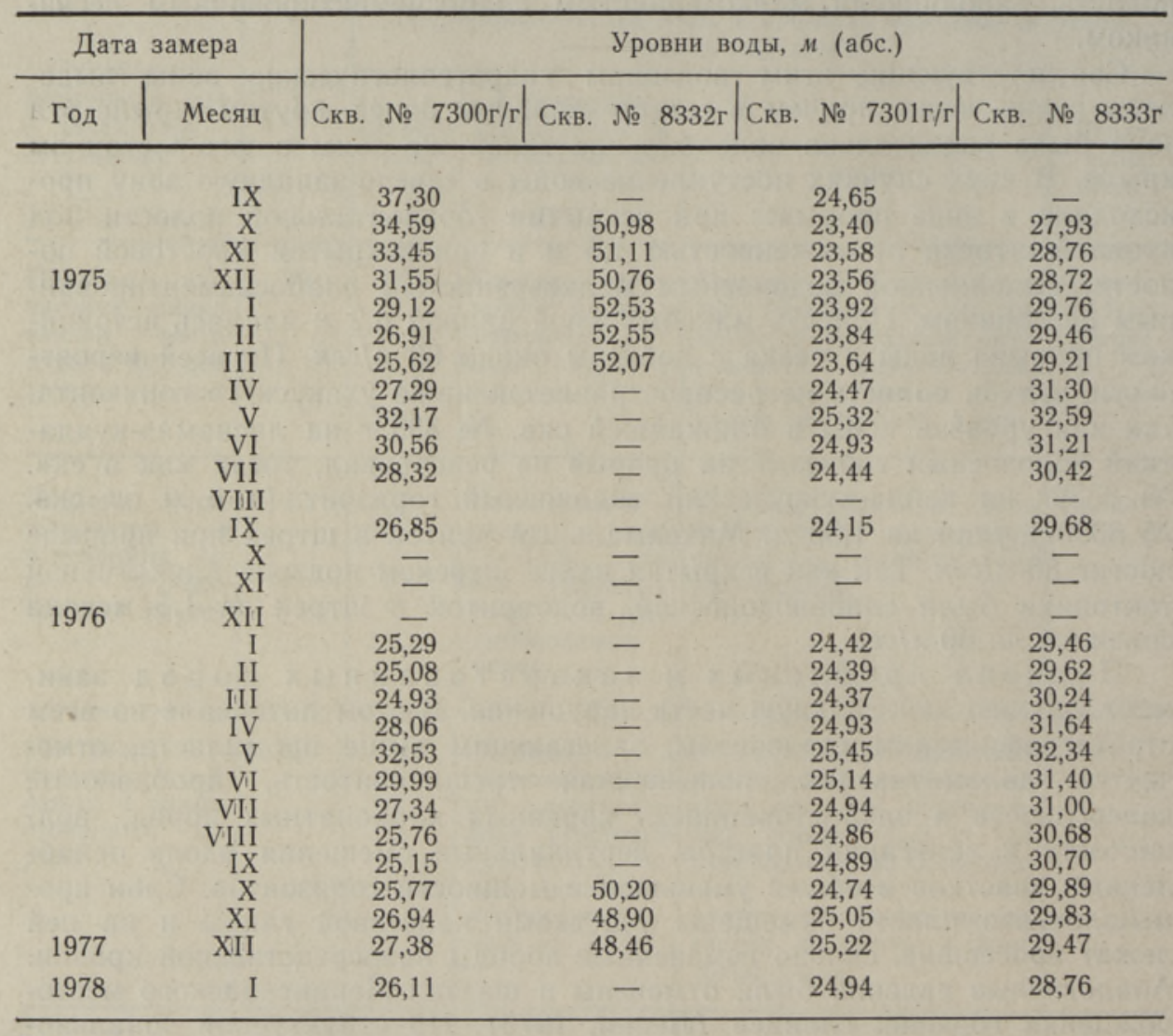

Величина снижения уровня

11,19

2,52

Установлено сходство химического состава воды из скв. № 7300г/г на кейла-кукрузеский водоносный горизонт и воды из штрека, в то время как подобное сходство с водой ласнамяэ-кундаского водоносного горизонта (скв. № 7301г/г) не обнаруживается. При сопоставлении химического состава подземных вод авторы пользовались методическим приемом, изложенным П. Иыгаром и В. Олли и примененным ими для Пандивереской возвышенности (Иыгар, Олли, 1973). За меру сходства при этом принят дистанционный коэффициент, т. е. разница в содержании шести основных ионов, выраженный в экв. \%. Дистанционный коэффициент, составляющий более 10 экв. \%, принимался в качестве признака разобщенности, а менее 10 экв. \% - в качестве признака выравнивания, обусловленного связью подземных вод (табл. 4,5$)$.

Проведенные исследования позволяют сделать следующие выводы:

штрек в северо-восточной части Ахтмеского нарушения дренировал преимущественно кейла-кукрузеский водоносный горизонт;

общий приток в штрек при пересечении всех основных водоносных зон возрос в 8-10 раз; 


\begin{tabular}{|c|c|c|c|c|c|c|c|}
\hline \multirow{2}{*}{$\begin{array}{c}\text { Номера } \\
\text { проб }\end{array}$} & \multirow{2}{*}{ Место отбора пробы } & \multicolumn{6}{|c|}{ Содержание ионов, экв. \% } \\
\hline & & $|\mathrm{Na} \cdot+\mathrm{K}|$ & $\mathrm{Ca}$ & $\mathrm{Mg} *$ & $\mathrm{Cl}^{\prime}$ & $\mathrm{SO}_{4}^{\prime \prime}$ & $\mathrm{HCO}_{3}{ }^{\prime}$ \\
\hline 1 & $\begin{array}{l}\text { Скв. № } 7301 \mathrm{r} / \mathrm{r} \text {, ласнамяэ- } \\
\text { кундаский водоносный го- } \\
\text { ризонт }\end{array}$ & 4 & 48 & 48 & 5 & 7 & 83 \\
\hline 2 & $\begin{array}{l}\text { Скв. № } 7300 r / r \text {, кейла-кук- } \\
\text { рузеский водоносный гори- } \\
\text { зонт }\end{array}$ & 3 & 67 & 30 & 3 & 37 & 56 \\
\hline 3 & $\begin{array}{l}\text { V сев. пан. штрек, подзона } \\
\text { трещиноватых и изменен- } \\
\text { ных пород юго-восточного } \\
\text { крыла }\end{array}$ & 3 & 67 & 30 & 4 & 26 & 63 \\
\hline 4 & $\begin{array}{l}\text { V сев. пан. штрек, подзона } \\
\text { трещиноватых и изменен- } \\
\text { ных пород северо-западного } \\
\text { крыла }\end{array}$ & 3 & 66 & 31 & 6 & 36 & 58 \\
\hline
\end{tabular}

таблица 5

\begin{tabular}{c|c|c|c|c|c|c}
\hline \multirow{2}{*}{$\begin{array}{c}\text { Сравни- } \\
\text { ваемые } \\
\text { номера } \\
\text { проб }\end{array}$} & \multicolumn{5}{|c}{ Дистанционный коэффициент по содержанию ионов, экв. \% } \\
\cline { 2 - 7 } & $\mathrm{Na}+\mathrm{K} \cdot$ & $\mathrm{Ca}$ & $\mathrm{Mg} \cdot$ & $\mathrm{Cl}^{\prime}$ & $\mathrm{SO}_{4}{ }^{\prime \prime}$ & $\mathrm{HCO}_{3}{ }^{\prime}$ \\
\hline & 1 & 19 & 18 & 2 & 30 & \\
$1-2$ & 1 & 19 & 18 & 1 & 19 & 27 \\
$1-3$ & 1 & 18 & 17 & 1 & 29 & 25 \\
$1-4$ & 0 & 0 & 0 & 1 & 11 & 7 \\
$2-3$ & 0 & 1 & 1 & 3 & 1 & 2 \\
$2-4$ & & &
\end{tabular}

наибольший приток наблюдался в структурной подзоне трещиноватых и измененных пород северо-западного (более крутого) крыла нарушения;

при вскрытии карстовых полостей поступление воды может носить характер прорыва.

\section{Л И Т Е Р А Т У Р А}

К а т т а й В., В и н ги с а а р П. Строение зоны Ахтмеского тектонического нарушения. - Изв. АН ЭССР. Геол., 1980, 29, 55-62.

Л е в н н А. С. К вопросу о характеристике деформаций в зоне древнего глубинного карста на Ленинградском месторождении горючих сланцев. - В кн.: Вопросы совершенствования технологии и комплексной механизации на сланцевых шахтах и разрезах. Кохтла-Ярве, 1973, 67-72.

Га з и з о в М. С. Карст и его влияние на горные работы. М., 1971.

И ыг а р П., Олли В. О влиянии тектонических нарушений и погребенных долин на гидрогеологические условия Пандивереской возвышенности Эстонской ССР. - Изв. АН ЭССР. Хим. Геол., 1973, 22, 358-361.

Эстонский филиал Ннститута горного дела им. А. А. Скочинского

Управление геологии ЭССР
Поступила в редакцию 21/XII 1979 


\section{AHTME TEKTOONILISE RIKKEVOOONDI KIRDEOSA HODROGEOLOOGILISED TINGIMUSED}

Ahtme rikkevööndi läbimisel kogutud hüdrogeoloogilise materjali ja keila-kukruse ning lasnamäe-kunda veehorisontidesse puuritud vaatluspuuraukude andmete alusel on iseloomustatud hüdrogeoloogilisi tingimusi tootsa kihi tasandil. Rikke struktuursed alavööndid langevad üldiselt hästi kokku hüdrogeoloogiliste vöönditega, mis on eristatavad vee juurdevoolu ning kindlate kvalitatiivsete ja kvantitatiivsete näitajate alusel. Vee üldine juurdevool strekki kasvab kõigi peamiste hüdrogeoloogiliste vööndite läbindamisel 8-10 korda. Strekk dreenib põhiliselt keila-kukruse veehorisonti.

\section{HYDROGEOLOGICAL CONDITIONS IN THE NORTH-EASTERN PART OF THE AHTME TECTONIC FAULT ZONE}

According to the hydrogeological materials obtained at prospecting in the Ahtme tectonic fault zone (the first experiment of its kind in the Baltic oil-shale basin), and stationary observations in boreholes in the Keila-Kukruse and Lasnamäe-Kunda waterbearing horizons, the hydrogeological conditions of the industrial stratum of kukersite oil shale have been characterized.

Within the limits of the fault zone studied, the structure of the latter is considered to be a complicated zonal one (Kattai, Vingisaar, 1980). The structural subzones are, on the whole, well correlated with the hydrogeological zones determined according to the water content, which have their own qualitative and quantitative characteristics.

Within the stretch of the main water-bearing zones, the total inflow increases $8-10$ times. The drift is mainly drained by the Keila-Kukruse water-bearing horizon. The degree of the seasonal changes of the inflow has also been stated. 